\title{
DISCOVERING ECONOMICS IN THE EU'S COMMON AGRICULTURAL POLICY. RECOMMENDATIONS FOR THE NEW PERIOD 2021-2026
}

\author{
Andrzej Czyżewski, Full Professor ${ }^{1}$; \\ Sebastian Stępień, PhD, Associate Professor ${ }^{2}$ \\ ${ }^{1}$ Faculty of Economics and Management, University of Zielona Góra \\ ${ }^{2}$ Faculty of Economics, Poznań University of Economics and Business
}

\begin{abstract}
The aim of the publication is to assess the functioning of common agricultural policy (CAP) in the context of its relationship with the paradigm of industrial and sustained development of the food economy. The idea is to find a relationship between specific instruments of the EU's agricultural policy and the assumptions of the adopted paradigms, and thus formulate certain general application premises and solutions in three areas: justification for the support of the agricultural sector, the problem of income deprivation of agricultural producers, and the change of the industrial-technological development model, predominant in agriculture, into sustained development. In light of the presented discussion, the occurrence of the following three economic CAP premises was confirmed: the need for financial support for the agricultural sector, the drainage of agricultural producers in the food supply chain, and the superiority of sustainably developed agriculture over industrial agriculture. As a result, recommendations concerning common agricultural policy after 2020 were given. The most important ones include: maintaining as high a level of support for agriculture as possible at an EU level, maintaining the system of direct subsidies as the most important instrument of equalising agricultural income, limiting unequal distribution of payments among small and large farms, enhancing the position of the farmer in the food chain, implementating a mandatory risk management instrument, and establishing an 'environmental budget' financing public goods.
\end{abstract}

Keywords: common agricultural policy, economics, paradigm, recommendations JEL codes: E60, E61, Q01, Q18

\section{INTRODUCTION}

The basic definition of economics treats it as a social science concerned with economic life. Its beginnings date back to the deliberations of ancient philosophers (Hesiod's and Xenophon's works on running a household, Plato's theory of the ideal state or Aristotle's chrematistics), and the period of geographical dis- coveries which enhanced the willingness to explore the regularities of the market mechanism. The real heyday of theory occurred in the 17th-18th centuries, and representatives of classical economics, such as William Petty, Adam Smith, David Ricardo, and Jean-Baptiste Say, have become an inherent part of the canon of humanities (Hull, 1899; Vaggi, 1987). Since that time, successive economic currents have

\footnotetext{
${ }^{1}$ Corresponding author: Podgórna 50, 65-246 Zielona Góra, Poland

${ }^{2}$ Corresponding author: al. Niepodległości 10,61-875 Poznań, Poland, sebastian.stepien@ue.poznan.pl, +4861 8543021
} 
made attempts at explaining economic development, both in macro- (Smith, 1776; Keynes, 1936) and microeconomic terms (Marshall, 1920; Robbins, 1932), differing as to the causes, course, and consequences of this phenomenon. The views of the followers of the neoclassical or neoliberal schools and those of Keynes and institutional schools on the role of the state also differed.

Nowadays, diversification of opinions and views is particularly high, among others on account of the nature of the global economy and the processes that accompany it and due to the development of science as such (Bartkowiak, 2010). More and more frequently, they go beyond national borders and involve decisions made by supranational entities of the political sphere (e.g. EU institutions). Consumer and producer economics (with the consumer and producer as entities active in the market) was replaced with the public choice theory (Wilkin, 2009). It is a useful tool for examining phenomena of political, economic, and social nature and may be successfully used to analyse specific activity of institutions of national and supranational reach. From the point of view of common agricultural policy, the public choice theory may serve as a search tool for selected paradigms of economics within its framework.

The aim of the publication is to assess the functioning of common agricultural policy (CAP) in the context of its relationship with the model of industrial and sustained development of the food economy. The idea is to find a relationship between specific instruments of the EU's agricultural policy and the assumptions of adopted models, and thus formulate certain general application premises and solutions in three areas: justification for the support of the agricultural sector; the problem of income deprivation of agricultural producers, i.e. the continuing disparity between agricultural and non-agricultural income in the conditions of average pay level growth in the economy; and the change of the industrial-technological development model, predominant in agriculture, into sustained development, considering that the second and third areas pertain to the need for support of agriculture (the first area), from different perspectives.

The significance of the problem adopted in the study arises from the fact that we are now on the eve of negotiations on the EU budget in a new financial perspective. It would be desirable for certain arguments to become a basis for formulating demands as to the shape of common agricultural policy. Searching for new solutions for agriculture no longer remains in the sphere of economists' aspirations, but is a necessity in a situation where industrial agriculture keeps bringing more and more socially and environmentally destructive side effects (Zegar, 2010; Czyżewski and Matuszczak, 2015). The article is not only a review and apart from the presentation of the theoretical bases of agricultural economics and the mechanisms of $\mathrm{CAP} \mathrm{f}$ unctioning, this research procedure contains elements of critical analysis of source literature, metaanalysis, and valuation, and is complemented with recommendations as to the shape of the EU's common agricultural policy after 2020 . At the same time, the publication is a response to the November 2017 announcement of the European Commission concerning the future of CAP (European Commission, 2017).

\section{PARADIGMS OF ECONOMICS IN COMMON AGRICULTURAL POLICY}

\section{On the need to support the agricultural sector}

The framework of common agricultural policy dates back to the late 1950s (in practice CAP was launched in 1962). It was then that the six countries making up the European Economic Community decided to define the objectives of intervention policy in the food sector in order to rebuild the production potential after the damage caused by World War II (Jambor and Harvey, 2010). In subsequent periods, its principles and directions of funding changed, yet in spite of the occurrence of critical remarks as to the essence of support for agriculture, the continuity of budgeting of this sector of the economy remained a distinctive characteristic. To date, attempts at limiting or even doing away with agricultural policy have met with opposition from most EU countries, even in the period in which the neoliberal economic doctrine prevailed in the mainstream (the 1980s and 1990s and the early 21st century (Mączyńska and Pysz, 2014). So what premises determine the need to maintain the support of the agricultural sector? If a liberal point of view with its study of micro- 
economic rationality was adopted, it would have to be assumed that state interventionism (or, in our case, EU interventionism) is an unjustified privilege of the food sector and it burdens the entire society with costs. However, this kind of reasoning fails to take into consideration the specific determinants of the agricultural market and the land factor, such as the compulsion to consume food and the lack of its substitutes, low price and income flexibility in the demand for agricultural products, a high share of the random parameter shaping the size of supply (dependence on natural and climatic factors), limited mobility and non-portability (massiveness) of the property invested in farms or a long capital payback period (Czyżewski, 2007). The characteristics of the agricultural sector also include its non-uniformity, resulting from the properties of the production factor - the quality of soil, the surroundings, location, and agrarian structure, and the fact that it does not meet the free market criteria, including a large number of buyers and sellers (or actually a balance in terms of the impact of these two parties to the transaction), the freedom to enter and leave the market, and finally, perfect information. Moreover, weather changeability and natural (biological) adaptation processes determine the higher degree of the seasonal and cyclical nature of supply and prices than in other sectors, contributing to the lack of income stability and difficulties in management (Stępień, 2015).

This way, production conditions unfavourable to agriculture entail ineffective allocation of production factors. In market conditions, farmers come under huge pressure to increase productivity, production scale, and specialisation, which hinders the fulfilment of non-commercial functions. At the same time, the market - guided by the principle of equalising marginal costs - favours concentration of agricultural production in the regions adapted to it and the disappearance of production in areas with less favourable natural and economic conditions. A liberal approach to the agricultural sector passes over the external effects accompanying agricultural production, both the negative ones, such as the deprivation of the weaker farms (which is discussed further on in the article) and the degradation of the natural environment, and the positive ones, related to the supply of public goods.
The scale of the problem grows in conditions of globalisation and the increasingly stronger position of transnational corporations. Economic effectiveness is becoming a priority and this means locating capital where profits are highest, often in places with lower environmental requirements or lower requirements concerning the well-being of animals or technologies used. Extending the journey made by food 'from the field to the table' creates an opportunity - due to anonymity - to introduce products of worse quality to the market, to the detriment of people's health (Czyżewski and Stępień, 2017).

Taking the above into consideration, one may conclude that the implementation of CAP mechanisms corrects the failures of the market mechanism and is justified from the point of view of economic, social, and environmental criteria. Thanks to financial support, the Community supports the so-called European agriculture model, which emphasises the duality of its function - apart from producing food, it contributes to the broadly defined development of rural areas and provides public goods (Committee of Agricultural Organisations in the European Union/General Committee for Agricultural Cooperation in the European Union, 1999; Fischler, 1999; Kowalczyk and Sobiecki, 2001). What is more, the observation of the consecutive periods encourages the conclusion that the response to incorrectly designed policy was the reform of CAP objectives and the adaptation of new solutions to these objectives. And so, after over more than 50 years of functioning, it has changed from a market-price policy, through an income and structural policy, to an environmental policy. Hence a reorientation of budget expenses occurred - from those oriented at constant growth of the productivity of production factors through high prices of food to those which directly make up the source of the farmer's income, while at the same time caring about the development of rural areas and natural conditions.

\section{Limiting income deprivation}

The above discussion justifies the conclusion that one of the paradigms of common agricultural policy is the need to maintain support for the sector. A lack of such a mechanism gives rise to the problem of 
relative, i.e. in relation to the non-agricultural surroundings ${ }^{3}$, income deprivation of farms occurring in free market conditions (cf. Czyżewski and Poczta-Wajda, 2016; Czyżewski, 2017). It turns out that without financial help, agricultural income in many highly developed countries is not only much lower than non-agricultural income, but also insufficient to cover the current operating costs and provide fair remuneration for work (Goraj, 2009; Czyżewski and Kułyk, 2010). So what are the underlying reasons for this disproportion in income? One should look for answers in the essence of land itself as a specific production factor. In the process of shaping indirect and final demand, rents (remuneration) from land participate in the distribution of surplus due to the lack of internalisation, i.e. taking into consideration numerous costs (e.g. maintaining the well-being of the natural environment) and the lack of fees for the public goods provided, to an inadequate extent. It is therefore true that the added value produced by agricultural producers does not meet the criterion of optimal allocation in the Pareto sense in intersectoral flows. In the supply chain, it is partly 'seized' by purchasers, processors, sellers, and finally consumers. This is caused, as Zegar points out, mainly by the operation of the market mechanism (Zegar, 2010). By means of prices, the market - based on property rights and supply and demand regulations - creates demand for money. In the real sphere, this leads to the concentration of production in order to lower its unit costs (in narrow microeconomic terms). Combined with technical progress, we obtain an increase in the production of agricultural raw materials in conditions of decreasing real prices of food ${ }^{4}$. The beneficiaries of this process include highly industrialised agricultural enterprises, which - through economies of scale - are becoming effective in the microeconomic sense, but with minimum requirements as to the quality of food, the well-being of animals, and the protection of the natural environment. For traditional, family farms (and these prevail e.g. in the Polish agrarian structure), income is significantly lower than the average for non-agricultural activity. The scale of disproportion is increased by the progressing globalisation process, which - through mergers and acquisitions - creates more and more processing and commercial corporations (such as Nestlé, Unilever, Craft Foods) which compete with one another for consumers using lower prices (Czyżewski and Czyżewski, 2015). A similar phenomenon occurs at the level of suppliers of goods and services for agriculture, where huge conglomerates use their monopolistic position and drain agricultural producers (not to mention giants such as Monsanto, Bayer, BASF, and Syngenta).

A consequence of the relationships described above is the need to return this part of the produced economic surplus which outflowed from the producers of raw material through a mechanism of income redistribution to the taxpayers (consumers), formerly through the market (minimum prices, intervention buying-in), and now primarily through the budget (subsidies and subventions of various types). A support mechanism of this kind constitutes a compensation of market discrimination of agriculture and is an important premise of the EU's common agricultural policy. At the same time, the CAP experience teaches us that the return of this surplus by supporting market prices significantly destabilises the market. Hence, as a result of an evolution of rules and instruments of the EU's agricultural policy, the lost value is returned through the budget, mainly in the form of direct subsidies (today mainly unrelated to production). They correct the failures of the market mechanism and decrease the scale of income inequality between agricultural producers and remaining market participants. This is proven, for instance, in research by Stępień,

\footnotetext{
${ }^{3}$ The term 'relative deprivation' was used intentionally, in order to ensure a proper standard of living for the rural population. It is necessary not only to absolutely increase income, but also decrease the differences between income in the agricultural sector and remaining sectors of the economy.

${ }^{4}$ Considering the last several decades, it can be observed that the current food prices, in real terms, are lower than the prices from the mid-1970s, even given the much higher prices of means of production (fertilisers, plant protection products, fuels, energy, etc.). Reaching back further, it should be emphasised that the long-term trend of agricultural price scissors getting worse has been ongoing since the 1880 s.
} 
Guth and Smędzik-Ambroży, concerning the diversification of the income of farms in the European Union and their non-agricultural surroundings (Stępień, Guth and Smędzik-Ambroży, 2017). The results clearly indicate that thanks to CAP support, the average income of farms came close to the average values of income in non-agricultural sectors. For example, taking into consideration the value of subsidies received by farms in Poland has increased the relation of their income to non-agricultural income from 30 to $70 \%$ (on average for the years 2004-2013). Similar conclusions were previously formulated e.g. by Sobczyński (2008) and Drygas (2010).

\section{Striving for sustainable development}

In search of the desirable path of development of the agricultural sector, it may initially be assumed that the industrial-technological model, predominant in the contemporary world, stimulating the technical effectiveness of production, has reached its limits of further growth. It is impossible to permanently increase labour and capital productivity in conditions of relatively low real buying-in prices. Industrial agriculture failed to meet two primary objectives of farming (Thirtle et al., 2004). Firstly - it failed to ensure proper income parity for the majority of farms, secondly - along with an increase in the scale and concentration of agricultural production, it degraded the standard of living in rural areas more and more, without internalising external costs in any way (Czyżewski and Czyżewski, 2015). These include both social costs - for instance, the previously mentioned income deprivation of agricultural producers, maintaining the disparity relative to non-agricultural holdings when it comes to the standard of living, sometimes leading to the depopulation of rural areas, and environmental costs - soil degradation, excessive emissions of carbon dioxide, eutrophication of watercourses and water reservoirs, steppe formation, etc. (Smędzik-Ambroży and Czyżewski, 2015). Considering the above, the model of sustainable agriculture is a kind of alternative to industrial agriculture.

The argument mentioned here became a basis for the construction of a CAP intervention system which would take into consideration economic, social, and environmental criteria. This was reflected in the change of the support structure from export-oriented market support into income-oriented support first, and later rural development and increasingly, environmental issues. The establishment of the so-called second pillar of the common policy in 1999, within the framework of the Agenda 2000 reform (Duer, 2000), responsible for sustainable and multifunctional development of agriculture, was particularly significant. The money that it provides plays an important modernisation and development-oriented role, increasing the competitiveness of the agricultural and food sector, thus serving an economic function. It also contributes to the improvement of the standard of living in rural areas, among others through the development of infrastructure, creating non-agricultural jobs, funding projects related to education, culture, tradition, etc., thus serving a social function. Finally, it creates tasks related to the protection of nature, maintaining biodiversity, the greening of food production, thus serving an environmental function. Moreover, as part of direct subsidies, certain rules were established which in their essence serve the creation of public goods. They make the granting of aid conditional on meeting a number of requirements related to the protection of the natural environment, people's health, the health of plants, and the well-being of animals (the so-called cross compliance, and currently also the so-called 'green' area payments).

\section{CONCLUSIONS AND RECOMMENDATIONS}

The discussion presented in the article leads to the final conclusion that in the practice of the EU's common agricultural policy, certain universal economic premises referring to the system of values resulting from the specificity of the land factor may be observed. The first one concerns the need for financial support for the agricultural sector, because the argument that the market mechanism is effective for lasting development of the agricultural sector is an idealisation of reality. In fact, agriculture's market orientation, along with attempts to increase productivity and technical progress, leads to structural changes in rural areas, which is manifested in the concentration of production and land consolidation. A negative consequence of these trends is the formation of mono- and oli- 
gopolistic structures, and later, income depreciation of small and medium-sized family farms. The latter do not participate in the process of creating the final product in an equivalent way. A large part of the economic surplus they produce is regularly 'seized' by purchasers, processors, sellers, and finally consumers themselves. This peculiar drainage of agricultural producers constitutes the second important premise of the pursued agricultural policy. Finally, the third economic premise concerns the new paradigm of development of the agricultural sector, the so-called sustainably developed agriculture, emphasising the equality of economic, social, and environmental objectives.

In this context, there is a need to determine the priorities of common agricultural policy after 2020 on the eve of negotiations on the new shape of the EU budget. Firstly, it is necessary to strive to maintain as high a level of agriculture funding as possible at an EU level. Renationalisation of support would be unfavourable for less wealthy countries, such as Poland. It would be a good idea to keep the two pillars of support. Above all, it is important to maintain the system of direct subsidies in the 1st pillar, as in practice, this is the most important instrument of equalising agricultural income relative to non-agricultural income. Secondly, we need to limit the problem of unequal distribution of support among small and large farms (Bournaris and Manos, 2012; Swinnen, 2015; European Commission, 2016; Matthews, 2016; Stępień, Guth and Smędzik-Ambroży, 2017), suggesting proper corrective action, e.g. degressive payments or setting the upper limit of annual funding or the agricultural area for which the producer would receive support. Solving the problem of income deprivation also requires the enhancement of the farmer's position in the food chain, which means the need to continue programmes aimed at the creation of agricultural producer groups and cooperatives and to support tasks increasing the added value of the farmer/ producer, marketing activities, etc. At the same time, the implementation of a mandatory - not voluntary as it is now - risk management instrument (e.g. in the form of mutual insurance funds) is called for. For this purpose, each country would create a special reserve, within the framework of the second pillar of
CAP. Other important tasks of rural development programmes should include tasks concerning the creation of new sectors of the economy, such as clean energy, bio-economy, circular economy, eco-tourism, and others. It is reasonable to maintain flexibility in the choice of directions of support for member states. Thirdly, when it comes to the orientation of CAP towards environmental objectives, it may be concluded that more requirements for farms will make food production more expensive and more complex. The thing is not to put pressure on further limits, but to manage the environment more effectively within a limited budget. So the idea is to develop a package of precise solutions for the natural environment, for which the farmer would receive remuneration (treated as remuneration for public goods), as additional income apart from area payments. In order to avoid double funding ('greening' in the first pillar, agri-environmental payments in the second), it would be appropriate to create a single budget (an 'environmental budget', as a potential separate pillar), funded from part of the area subsidy envelope and from savings made by limiting support for the largest farms. In this context, the instrument would be addressed mainly to smaller farms, functioning as suppliers of public goods and 'landscape guards', and by moving some direct support to the environmental budget could be treated as providing equal opportunities to small and medium-sized farms.

\section{REFERENCES}

1. Bartkowiak, R. (2010). Współczesne teorie ekonomiczne [Contemporary economic theories]. Roczniki Nauk Rolniczych, Seria G, 97 (20), pp. 16-29.

2. Bournaris, T., Manos, B. (2012). European Union agricultural policy scenarios' impacts on social sustainability of agricultural holding. International Journal of Sustainable Development \& World Ecology, 19, pp. 426-432.

3. Committee of Agricultural Organisations in the European Union/General Committee for Agricultural Cooperation in the European Union (1999) The European Model of Agriculture - The Way Ahead. $\operatorname{Pr}(99) 88$ F1.

4. Czyżewski, A. (2007). Makroekonomiczne uwarunkowania rozwoju sektora rolnego [Macroeconomic determinants of agricultural sector development]. In: 
Czyżewski, A. (ed.) Uniwersalia polityki rolnej w gospodarce rynkowej. Ujęcie makro- i mikroekonomiczne [Universals of agricultural policy in a market economy. Macro- and microeconomic approach]. Wydawnictwo Akademii Ekonomicznej w Poznaniu, Poznań, pp. 15-23.

5. Czyżewski, A., Czyżewski, B. (2015). Ziemia i jej renty w nowym paradygmacie rozwoju rolnictwa [Land and its rent in a new paradigm of agricultural development]. In: Czyżewski, A. and Klepacki, B. (eds) Problemy rozwoju rolnictwa i gospodarki żywnościowej w pierwszej dekadzie członkostwa Polski w Unii Europejskiej [Problems of agri-food sector development in the first decade of Poland's membership in the European Union]. PTE, Warszawa, pp. 27-41.

6. Czyżewski, A., Kułyk, P. (2010). Relacje między otoczeniem makroekonomicznym a rolnictwem w krajach wysoko rozwiniętych i w Polsce w latach 1991-2008 [Relations between the macroeconomic environment and agriculture in highly developed countries and in Poland in 1991-2008]. Ekonomista, 2, pp. 189-214.

7. Czyżewski, A., Matuszczak, A. (2015). Potrzeba zmian w modelu rozwoju rolnictwa a finansowanie celów w budżecie rolnym Polki po 2005 roku [The need for changes in the agricultural development model and financing of objectives in the Polish agricultural budget after 2005]. Zeszyty Naukowe Uniwersytetu Ekonomicznego w Katowicach. Studia Ekonomiczne, 218, pp. 113-114.

8. Czyżewski, A., Stępień, S. (2017). Nowe uwarunkowania ekonomiczne wspólnej polityki rolnej (WPR) Unii Europejskiej [New economic conditions for the Common Agricultural Policy (CAP) of the European Union]. Ekonomista, 6, pp. 675-697.

9. Czyżewski, B., Poczta-Wajda, A. (2016). Effects of Policy and Market on Relative Income Deprivation of Agricultural Labour. In: Rural Jobs and the CAP. 160th EAAE Seminar. Warsaw, 01-02.12.2016.

10. Drygas, M. (2010). Wpływ dopłat bezpośrednich w ramach Wspólnej Polityki Rolnej 2004-2006 i 2007 2013 na przekształcenia obszarów wiejskich w województwie pomorskim [The impact of direct payments under the Common Agricultural Policy 2004-2006 and 2007-2013 on the transformation of rural areas in the Pomeranian Voivodship]. Expertise prepared for the Marshal's Office in Gdańsk. IRWiR PAN, Warszawa.

11. Duer, I. (2000). Agenda 2000 - podstawą rozwoju polskiego rolnictwa [Agenda 2000 - the basis for the development of Polish agriculture]. Pamiętnik Puławski, 120.
12. European Commission (2016). Report on the distribution of direct aids to agricultural producers (financial year 2015). Ref. Ares(2016)6181665.

13. European Commission (2017). Communication from the Commission to the European Parliament, the Council, the European Economic and Social Committee and the Committee of the Regions. The Future of Food and Farming. COM(2017) 713 final of 29.11.2017.

14. Fischler, F. (1999). The European model of agriculture - the future of modern farming. In: International Green Week. Berlin 21.01.1999.

15. Goraj, L. (2009). Wpływ wspólnej polityki rolnej na dochody polskich gospodarstw rolnych [The impact of the common agricultural policy on the income of Polish farms]. In: Polish vision on Common Agricultural Policy after 2013. Conference. Warsaw 26.01.2009.

16. Hull Ch.H. (1899). The Economics Writings of Sir William Petty. University Press Cambridge.

17. Jambor, A., Harvey, D. (2010). CAP Reform Options: A Challenge for Analysis \& Synthesis. Centre for Rural Economy Discussion Paper, 28, p. 3.

18. Keynes, J.M. (1936). The General Theory of Employment, Interest and MoneyPalgrave Macmillan, London.

19. Kowalczyk, S., Sobiecki, R. (2001). Europejski model rolnictwa - uwarunkowania ewolucji [The European agricultural model - determinants of evolution]. Roczniki Nauk Rolniczych, Seria G, 98 (3), pp. 9-20.

20. Mączyńska, E., Pysz, P. (2014). Liberalizm, neoliberalizm i ordoliberalizm [Liberalism, neoliberalism and ordoliberalism]. Ekonomista, 3, pp. 221-247.

21. Marshall, A. (1920). Principles of Economics. 8th ed. Macmillan, London.

22. Matthews, A. (2016). Focus on the distribution of direct payments. Retrieved from: http://capreform.eu/focus-on-the-distribution-of-direct-payments/ [Accessed 07.03.2018].

23. Robbins, L. (1932). An essay on the nature and significance of economic science. Macmillan, London.

24. Smędzik-Ambroży, K., Czyżewski, A. (2015). Specialization and diversification of agricultural production in the light of sustainable development. Journal of International Studies, 2, pp. 63-73.

25. Smith, A. (2007). An Inquiry into the Nature and Causes of the Wealth of Nations. Metalibri, New York.

26. Sobczyński, T. (2008). Zmiany udziału dopłat w dochodach gospodarstw rolniczych UE w latach 1989-2005 [Changes in the share of subsidies in the incomes of EU farms in the years 1989-2005]. In: Kopycińska, D. (ed.) Polityka Unii Europejskiej [Policy of the European 
Union]. Wydawnictwo Uniwersytetu Szczecińskiego, Szczecin, pp. 36-50.

27. Stępień, S. (2015). Cykl świński w świetle zmian na globalnym rynku żywca wieprzowego [The hog cycle in the light of changes in the global pork market]. PWN, Warszawa.

28. Stępień, S., Guth, M., Smędzik-Ambroży, K. (2017). Socio-economic sustainability of farms in Poland in terms of Common Agricultural Policy (CAP) of the European Union. In: Challenges in a Turbulent Era. The 5th International Conference of the Global Economy \& Governance. Warsaw 22-24.10.2018. Wydawnictwo SGGW, Warszawa.

29. Swinnen, J. (2015). The Political Economy of the 2014-2020 Common Agricultural Policy. An Imperfect
Storm. Centre for European Policy Studies - Rowman and Littlefield International, London-Brussels.

30. Thirtle, C., Lin, L., Holding, J., Jenkins, L., Piesse, I. (2004). Explaining the Decline in UK Agricultural Productivity Growth. Journal of Agricultural Economics, 55 (2), pp. 343-366.

31. Vaggi, G. (1987). The Economics of Francois Quesnay. MacMillan Press, London.

32. Wilkin, J. (2009). Ekonomia polityczna reform wspólnej polityki rolnej [Political economy of reforms of the common agricultural policy]. Gospodarki Narodowa, $1-2$, pp. $1-2$.

33. Zegar, J.S. (2010). Ekonomia wobec kwestii agrarnej [Economics in the context of agrarian issue]. Ekonomista, 6, pp. 779-804. 